\title{
China and the Steppe: Reception and Resistance
}

\author{
Jessica Rawson \\ School of Archaeology, University of Oxford, Institute of Archaeology, 34-36 Beaumont \\ Street, Oxford OX1 2PG. \\ Jessica.Rawson@merton.ox.ac.uk
}

\begin{abstract}
The early dynasties of central China, the Shang (c.1500-1046 BC) and the Zhou (1046-771 $\mathrm{BC}$ ), were continually pressured by many diverse groups on the borders, who in turn were in contact with the steppe. In consequence central Chinese societies took over bronze casting, chariots in warfare and iron from the steppe through the borderlands. These were, however, developed within central Chinese systems, with high levels of production, serving China's ritual and state traditions. Materials, such as gold, or items, such as the sword, which could not be adapted in this way, were not readily borrowed from the border peoples.
\end{abstract}

The peoples on China's borders and beyond, the mobile pastoralists of the steppe, have traditionally been described in derogatory terms based upon comments in the early histories of the fourth to first centuries BC (Di Cosmo 2002, 97-104). A project at the University of Oxford's School of Archaeology, funded by the Leverhulme Trust, has worked with a rather different perspective, namely that China's societies and culture were stimulated and enriched by contact with the borders and the steppe. Ongoing research has tracked metal chemistry (Hsu et al. 2016), examining transfers across the Eurasian steppe to China; it has followed river routes within China and along mountain corridors in eastern Eurasia (Frachetti 2012); above all, the research has focussed on the conditions that enabled transfers of materials and ideas into central China and those that inhibited them in the Shang (c. 1500-1046 BC) and Zhou (1046-221 BC) periods.

The China discussed here comprises the lower Yellow River and the valley of the Wei, known as the Central Plains. Over the first millennium BC, central Chinese culture was extended to the northern bank of the Yangtze. One major conclusion is that, although some essential technologies and ideas were introduced from the steppe, such as metallurgy and the management of horses (first for chariots and later for mounted warfare), these were developed in ways completely unlike the practices in their places of origin. By the third millennium BC, the inhabitants of central China had already established complex societies 
and were only attracted to materials from outside if these could be adapted to fit their wellembedded practices. In thinking about why some exchanges were inhibited, we have made use of and developed the concept of an arc, wide borders of land between the eastern steppe and China, a concept that came to fruition in the 1980's (Lin 1986: 241-250; Tong 1987).

In general, the overall developments of China and the steppe have been and are still generally discussed independently of each other. Some scholars have postulated a symbiotic relationship (Barfield 1989: 8-20). Others have concentrated on the penetration of some steppe customs, particularly the chariot, into northern China (Wu 2013). As a result of extensive excavation in the Russian Federation (Chernykh 1992, Kuzmina 2008) and China (CASS 2003) views have changed. The border area, the arc, has also attracted a lot of attention (Di Cosmo 2002: 49-74; Linduff 1997: 18-32). Surveys have identified typological similarities of weaponry across the steppe and into the borders (Wu 2007; Yang \& Shao 2014).

The first steps towards an understanding of what contacts across this vast region meant to China have been made in recent decades by scholars examining the ways in which cereals, wheat and barley, and metals, especially bronze and iron, came into the Central Plains (Jones 2011; Mei et al 2009; Linduff 2015; Lin 2015; Li 2015). The transfer of the chariot and horse to China has been under discussion for a much longer period, culminating in recognition of the dependence on prototypes in the steppe for the construction and management of chariots (Wu 2013: 37-45). The wider implications of the importance of contact between Eurasia and China were drawn together by Andrew Sherratt, who noted that, had this 'Trans-Eurasian Exchange' not existed, China might have remained as isolated from western Eurasia as the Americas were when Columbus reached the islands of the Caribbean (Sherratt 2006: 35-36).

\section{Geography: The Arc and Central China}

Fundamental to this account are the environmental and social differences of three major areas, the Eurasian steppe, the arc, and central China, that is, the Central Plains. Across many thousands of kilometres, pastoralists and agropastoralists were often mobile, at least seasonally, with varied practices of trade, ritual communication, political negotiation, herding and exploitation of resources (Frachetti 2012). They also sought wealth and power by forming alliances, breaking them again and forming new ones, vying for allegiances with 
gifts that in themselves were also a means of spreading new materials and technologies (Kuzmina 2008: 40-70; Honeychurch 2015: 73). The great ranges of the Pamirs, the Tianshan, the Altai and the Sayan provided many regions rich in minerals and forests that fostered metallurgy. To the north, the basin of Minusinsk was especially favoured by mountains that sheltered its steppe and agricultural land (Legrand 2006).

Between the steppe and the Central Plains is a vast area of high land, desert, agricultural basins and some northern forest zones, which Tong Enzheng called the "crescent-shaped region” (Tong 1987). Others refer to Northern Zone, the Northern Frontier or the Northern Bronzes Complex (Shelach 2009:8, 28-30; Rawson 2015: 46-47). With different names, the area is now receiving more attention. It can regarded as extended in the west, southwards towards Yunnan. Here, we have adopted the term "arc" to describe this zone as an area of independent cultural groups (Figure 1). The arc shares with the steppe a climate generally less favourable for intensive agriculture than that of central China. It is mapped here, shaded grey, on the basis of relief and precipitation, but also of data, collated from official statistical publications of the People's Republic of China, relating to modern economic practices, to define the boundary between areas of intensive agriculture and those of mixed agriculture and livestock management (USDA/ERS and CIESIN, 1996).

This huge, geographically and ecologically diverse, area was inhabited by many different groups with varied material cultures. Three tendencies shared within the arc are relevant: Weaponry and tools had more in common with those of the steppe groups than with those of central China; bronze vessels, which we shall see were major products of the Central Plains, were acquired by trade or looting and sometimes copied (Rawson 2016); a leaded tin bronze alloy employed on the Central Plains was also widely adopted.

The Central Plains, by contrast, had and have quite different geographical and ecological features. A large territory, covered in the highly fertile loess blown from the north-west, nourished millet and rice agriculture, without much pastoralism, and allowed more people to be fed on the land than if it had been used intensively for herds. A relatively dense population was, except for periods of extreme warfare or famine, to be a continuing hallmark of central China (Shelach-Lavi 2015: 9-11). Long before the advent of metallurgy in the second millennium BC, communities had been organized for large projects, such as the construction of ditches, dykes and walls (Shelach-Lavi 2015: 127-160). The grains favoured, 
millet and rice, had to be boiled, not ground and baked, as were wheat and barley in Western Asia (Fuller \& Rowlands 2011: 46-51). One consequence was that all communities developed a wide variety of fine ceramics for cooking, serving and for rituals, such as burial.

High levels of organisation, required for grain storage, were fostered by the Neolithic ceramic industry in the Dawenkou and Longshan phases, fourth to third millennium BC (Underhill 2002: 63, 182-184), but also by the challenging materials, jade and silk. Sub-division of labour had evolved before the Shang dynasty (c.1500-1046 BC), enabling mass-production of very high quality items for elites in markedly hierarchical societies (Shelach-Lavi 2015: 156158, Ledderose 2000). Elaborate burials, especially in east coast third millennium BC Neolithic societies, materialised complex rituals in which jade, ceramics and lacquer played large roles. These were foundations of the Shang and Zhou dynasties' rituals, with a focus, not on a distant cosmos of deities, but on kin and their afterlife powers in the here and now.

Contrasts in the second millennium BC between the elaborate burials of the late Neolithic and Shang periods and those of the steppe and arc were stark. Typical of the western steppe, the well-known graves at Sintashta included weapons, ornaments, and animal remains as well rare chariot traces (Anthony 2007, 374, fig. 15.3). Burials in the arc at this early stage included ceramics, some bronze weapons and ornaments (Linduff 1997: 22-25). Despite many local variations and considerable changes in the first millennium BC, this basic division in tomb contents, driven by the roles and beliefs of their occupants, remained constant throughout the period under discussion.

\section{From the Steppe to China}

Two major phases of change in the second and first millennium BC, respectively, generated movement across the steppe and had direct impact on central China. The first was a long-term expansion of activity over the third to mid-second millennium BC, as increasing mobile pastoralism and metallurgy both spread across the steppe (Anthony 2007: 371-457; Frachetti 2012). Over this time period, copper and then bronze were used, primarily for weapons and a few ornaments, in South Siberia and the eastern steppe, carrying metal work into Xinjiang, as well as Mongolia and the Hexi corridor (Linduff 1998, 2015). The second phase, probably starting at the beginning of the first millennium, was energised by widespread horse riding. Here the hallmarks of contact that can be traced in the arc and central China are the use of iron and gold and motifs of animals, mainly in profile (Bunker 1993; Di Cosmo 2002:56-87). 
There was a debate, over more than half a century, on the origins of metallurgy in central China (Karlgren 1945; Loehr 1949). Today scholars generally accept that metal use entered China as metallurgy was adopted in the steppe and into the arc (Chernykh 1992; Linduff 2015; Mei 2009). Some early metal finds in the arc (in the Hexi corridor and as far east as Chifeng) are only explicable as the result of several separate contacts with peoples from different parts of the steppe (Linduff 1998). Much of this early metalwork was of arsenical copper, smelted from an ore or achieved by adding arsenic to the copper. But although this alloy was introduced into China at the major site of Taosi in Shanxi province (Lin 2015, fig. 3), the central Chinese chose to work with tin bronze, to which they added lead, as some earlier casters of the Qijia culture in the Hexi corridor had done (Mei 2009:10). Tin bronze developed in the steppe, as seen in the Seima Turbino phenomenon, which spread primarily westwards from the Altai (Chernykh 1992: 190-234; Lin 2015). Seima Turbino metalwork also impacted on the east: a spearhead-type with a projecting hook below the blade, originating in the Altai area, among other weaponry, was carried into China (Figure. 2). This connection ties some of the impetus for the choice of tin bronze in central China to such innovations (Mei 2009: fig. 3).

Following the initial impetus that brought metallurgy from the steppe into the arc and then into the Central Plains, three central Chinese innovations illustrate concurrent reception and resistance to this introduced technology: bronze used for vessels rather than primarily for weapons: warfare conducted with steppe chariots but without individual elite combat weaponry; and jade weapons in burials, replacing the personal bronze daggers and knives buried with peoples of the steppe.

The major Central Plains site at Erlitou, with elite structures, workshops and tombs, has provided evidence of the first moves, c. 1700- 1600 BC, to use bronze in an entirely local context (CASS 2003, 61-139). Although casters continued to make some objects derived from steppe or arc models (Shelach 2009:128), two developments drove bronze casting in new directions. Complex ceramic moulds were evolved to cast vessels based on the ceramic prototypes already mentioned, and lead was added to the alloys to ensure that metal flowed well into elaborately shaped and decorated forms (Figure 3). The sizes of the principal, late Shang and early Western Zhou (twelfth to ninth centuries BC), vessels were extraordinary, with the largest surviving vessel weighing 875 kilos. Sets of numerous bronzes for ritual 
banquet performances required immense efforts in mining, smelting, transport, mould making, casting and finishing (Figure 3). As bronzes were buried in tombs, new vessels were continually commissioned. The intensity and scale of labour required for the bronze industry were driving forces in expanding the numbers of Shang centres, as well elaborating extensive networks for the acquisition of resources, such as copper or ivory from the south and later horses from the north (Cao 2014: 198-205; Rawson 2016).

When the Zhou, a group from the northwest, defeated the Shang in 1046 BC, they employed modified forms of Shang ritual offerings and burial to establish their legitimacy and cast vessels and borrowed ritual practices to expand their power base. All the evidence shows that, in the hands of the Shang and Zhou rulers, when metallurgy from outside was embedded in the Central Plains, it became a major instrument in entrenching forms of ritual and power that underpinned their states and were unique to China.

The chariot appeared at the Shang court in the thirteenth century BC. Both the vehicle's form, with large spoked wheels, and the paired trained horses must have been introduced from the arc and the steppe, where they were first used east of the Urals in Sintashta, about 2000 BC (Kuzmina 2008: 49-59:). Such a completely new machine almost certainly needed steppe drivers and trainers for the horses, and we know that these were present at the Shang centre at Anyang from copies of steppe weapons found in their tombs (Rawson 2015: fig. 13). However, these originally foreign chariots were transformed for burial with the Shang elite, being decorated with local, mass-produced bronze plaques and fittings to enhance their ritual presence (Wu 2013: figs, 2.2, 2.19).

Both the Shang and the Zhou engaged in war with their northern neighbours as oracle bone and bronze inscriptions testify (Keightley 2012: 174-193; Li 2006: 141-192). But the dynastic armies did not adopt northern fighting patterns, based on small-scale bands of men, attacking with axes, daggers and bows and arrows, seen in finds from across the steppe and the arc (Yang and Shao 2014). Shang leaders carried huge bronze axes, derived from Neolithic jade prototypes. Such heavy blades were not suitable for hand-to-hand combat and there was no celebration of individual valour. The distribution of short swords and daggers mapped in Figure 4 shows that these were not taken far into central China in the Shang and early Zhou. 
Instead, from the Shang, infantry armies were large, consisting of several thousand men in the field. This number rose rapidly over the Western (1046-771BC) and Eastern Zhou (770221BC) to tens of thousands and, and finally to hundreds of thousands (Yates 1999: 26-27). Such forces, like other characteristic cultural patterns of the Central Plains, depended on a large population raising crops, rather than on herding animals.

Objects made from jade, the material most valued by the ancient Chinese, illustrate more subtle responses to the proximity and dangers of the arc and the steppe. From the Erlitou period, and especially under the Shang, pointed jade blades (Figure 5), mimicking bronze weapons, were carved in many sizes and with many different details to accompany the highest elites in death. The dangers posed by demons and spirits of the afterlife were sufficiently alarming to require defensive weapons in jade rather than bronze steppe-style daggers — as jade was, apparently, accorded auspicious powers.

The second phase of contact and exchange can be traced from the beginning of the first millennium and intensified from the eighth century BC. Pressure from the north, which led to the collapse of Zhou rule in the Wei valley in $771 \mathrm{BC}$ and the flight of the court eastwards to Luoyang, probably resulted from increased competition and conflict in both the steppe and the arc. Many groups had taken to horse riding for raiding and warfare and now used iron weapons (Di Cosmo 2002: 74-90; Honeychurch, 2015: 109-156). An increasing number of conspicuous stone monuments in the steppe,1400-700 BC, reflected these changes (Honeychurch 2015: 112-122; Jacobson-Tepner 2010; Jackson \& Wright 2014). In the succeeding period, seventh to fourth century BC, steppe leaders across an immense area from the Black Sea to the arc, were accorded massive burials under huge stone kurgans, with elaborate dress with gold ornaments and belts, accompanied by horses and subordinate burials. These individuals also were buried with impressive iron weapons, sometimes decorated with gold, and with golden scabbards (Figure 6).

A concurrent concentration on animal motifs has tended to be identified as Scythian. But as the centre of the early development of the so-called "animal style” was in the Sayan Altai region, the term Siberian or Scytho-Siberian would be more appropriate (Di Cosmo 2002: 32). Two tomb groups here are especially relevant to developments in the arc and central China, those at Arzhan in the Tuva, dating from the ninth to seventh century BC (Chugunov et al. 
2010), and those of the fourth to third century BC at Pazyryk in the Altai, where gold foil on wood, rather than solid gold, was used (Rudenko 1970: pl. 120).

Certainly the speed with which gold, iron and animal motifs reached the arc is astonishing. A lord of Rui, buried in tomb M27, dating to the eighth century BC, at a large cemetery at Liangdaicun, near Hancheng on the Yellow River, where it flows south, must have been a near contemporary of the individuals buried at Arzhan. Not only did the lord have iron blades set in bronze as steppe-style knives, he had the largest assemblage of gold ornaments found so far on the edge of central China (Figure 7). The Rui lord also had a jade copy of a Tagartype dagger in an openwork gold scabbard (So 2012, fig. 3); such daggers were popular in the Minusinsk basin and, beginning in the eighth century, appeared in many variations in the arc, with even one example buried in a Han prince's tomb at Mancheng, in the second century BC (Figure 6).

In the fourth to third centuries BC, steppe motifs and practices from the Altai, known from the burials at Pazyryk, were transmitted enormous distances to Majiayuan in Gansu province and other sites in the arc (Figure 6). The nearly sixty tombs at Majiayuan were occupied by steppe or arc peoples, buried not in Chinese style shaft tombs, but in catacombs with niches. The occupants of these tombs, like their steppe contemporaries, wore gold plaques on their belts and curved ornaments around their necks; their clothes carried masses of beads, and they were interred with horses and cattle heads and hooves; none of these items figured in burials in central China (Gansu sheng 2014: 58-63). The highly decorated chariots in these tombs were unusual. If we look at the Majiayuan objects in more detail, we can see that small animals cut out of sheets of gold, silver or tin closely resemble those in felt and leather found at Pazyryk (Gansu sheng 2014: 72-84, Rudenko 1970: figs. 108-115, 137). As at Pazyryk also, the Majiayuan peoples took over Mediterranean motifs of palmettes and running scrolls introduced to the steppe from Western Asia (Stark 2012; Gansu sheng 2014: 88, 92, 94, $104-$ 106: Rudenko 1970: fig. 72, pls. 67, 79, 82, 143, 148, 152, 155: C, 162).

The speed with which the Majiayuan peoples borrowed practices and motifs from the distant Altai contrasts with the resistance of the peoples of central China to adopting these. Gold was used, but hesitatingly and with a variety of experiments with gold foil, cast gold vessels and fittings and gold inlaid inscriptions (Bunker 1993). Only for a relatively short period in the Western Han (206BC-AD6) were exotic gold and silver items highly prized (Nanjing 
Museum 2013). Bronze and jade remained the materials of primary value until, from the fourth century AD, Buddhism brought with it notions of jewelled and gilded paradises.

Weapons from the steppe, especially the sword, although fairly common by sixth to fifth centuries BC, do not seem to have radically changed the tactics of war. Some soldiers must have carried swords and employed them in battle, but there is no evidence that elite commanders personally engaged with swords against their equals. From texts we learn that swords were more likely employed in suicide, ambush or assassination (Rawson 2015: 70).

However, if steppe sword fighting and golden ornamented dress from the sixth century BC failed to make a strong impression in the Central Plains, iron, as bronze had earlier, met important needs. As with bronze, the Chinese did it their own way; they cast iron at very high temperatures, which were not attained further west for over a millennium. Massive numbers of cast iron tools enabled the central Chinese to expand further north and south into more difficult territories, thus developing central Chinese society and its influence (Wagner 2008: 115-170 ). An expansion of agricultural land followed, and the rulers of the now divided Central Plains, in the period known as the Warring States (c. 475-221 BC), pushed northwards, engaging further in combat with their neighbours.

\section{The Arc and the Rise of the Qin State.}

The peoples of the arc thus played major roles in the development and changes of the societies of the Central Plains. We have noted three conspicuous innovations: bronze for ritual vessels, the chariot and the development of iron were all brought to the Shang and later the Zhou through the arc. Other innovations, such as horse tack, swords and inlaid ornament of copper, gold and silver were also introduced this way too, but made less impact on social practices as a whole.

From the fourth to third centuries BC onwards, the Chinese became conscious of the distinctive cultural demands of the steppe. They, therefore, supplied their neighbours with gold and bronze belt buckles and ornaments in steppe style (Bunker 1993: 45-46). Silk and occasionally Chinese types of chariot were sent north and appear in Pazyryk tombs (Rudenko 1970: fig. 17, pl. 178). But while Chinese ritual vessels were also exchanged with or captured 
by the peoples of the arc, typical central Chinese bronze and jade forms and motifs did not, in general, find their way through the arc to the steppe.

The peoples of the arc, to a large degree, and certainly the inhabitants of the wider eastern steppe did not take up the major central Chinese innovations that had originally been stimulated by contact with the north, namely bronze vessel sets, chariot ornaments in bronze and mass-production iron casting. A fundamental reason for an indifference or barrier to these practices was a difference in ideology. In central China, offering rituals with complex bronze vessels for food and drink were linked directly to the belief in the power of the ancestors and placed attention on social and kin relations of the living world, not on a distant cosmos. The ideologies of the arc and the steppe were not congruent, and though we have little textual information on the steppe, we can suggest that there were interests in Heaven and animal spirits, ideas that later crystallised as Shamanic beliefs.

In addition, large bronze and iron industries depended on a high level of organisation, as well as on complex hierarchical societies that created the demand for numerous bronze and later for iron weapons and tools. Most areas of the arc, and all of the steppe, were too sparsely populated, with limited access to resources such as grain and minerals, to provide both the supply and consumption that drove forward Chinese industries. As a result much of the movement of new ideas and of materials was from the north, the northwest and the northeast towards the centre. It was also from this direction that significant intrusions of outsiders came.

Of course, both the Shang and the Zhou went north as well, having to campaign against peoples from the arc, as they sought new territories, new materials and above all horses. The invasion of the Zhou into the Wei River and the defeat of the Shang in 1046 BC, a battle that was fought with support of other outsider groups, is, however, clear indication of the drawing power of the Central Plains. And this movement towards the dynastic centres was repeated by attacks by others, known as Rong or Xianyun, into Zhou lands during the ninth and eighth centuries, leading to the movement of the capital to the east to Luoyang in 771 BC (Li 2006: 141-192).

As the Zhou moved their centres eastwards, their territory was gained by the aspiring state of Qin. Yet, despite having moved their political centres into the Wei valley, some early Qin lords were buried in their home territory further west, in present day Gansu at Li Xian. In the 
eighth and seventh centuries BC, they interred sets of bronze vessels in accordance with central Chinese tradition. But at the same time, some bronzes, especially those from Yuandingshan, were embellished with small three-dimensional animals typical of the steppe; numbers of gold ornaments, also typical of the steppe, have been found there and in the western Wei valley (So 2012, fig. 2; Michaelson 1999, nos. 1, 2, 8). Over the following centuries, the Qin followed Zhou ritual practices fairly closely, but from the fourth century BC returned to a more hybrid combination of northwestern customs in some of their tomb structures, while adopting central China’s palace buildings (Shelach and Pines 2005: 216).

King Zheng of Qin (246-221BC) , who was to be the First Emperor (221-210 BC), took material from many regions. When established as the First Emperor, he employed steppe cavalry men in his army, as we now recognise from the terracotta warriors guarding his tomb (Khyayutina 2013, no.314), whose dress resembles that of steppe leaders known to the Achaemenids and Parthians (Curtis 2000, front cover), but he proclaimed his conquest in the language of the Central Plains, Chinese. He must have had advisors who knew something of the seals, weights and measures of Central Asia and Iran (Khayutina 2013, nos. 115-117) and retained craftsmen who had mastered western technologies and cast bronze birds for his tomb in hitherto unknown life-like forms (Mei et al. 2014). The First Emperor also exploited the mounted horsemen and iron weaponry originally from the steppe and the agricultures and settlements of the centre, turning to the extraordinary organisation of people and manufacture on the Central Plains to create a unified state. This could only be achieved by moving towards the centre, as the Emperor indeed did.

As the Qin moved south and east, like the Zhou before them, they adopted central Chinese organisation. Later dynasties founded by outsiders did the same. Yet even though northerners might take over as rulers of the Central Plains, the materials, technologies and ideas that they brought with them were only embedded there when these could be adapted to and integrated within the highly organised hierarchical societies that had come into being long before the arrival of metallurgy from the west.

\section{Acknowledgements}

The research has been supported by the Leverhulme Trust Grant F/08 735/G for work by Peter Hommel, Beichen Chen, Yiu-Kang Hsu and Rebecca O’Sullivan; the research has also 
been supported by the Reed Foundation and the China Academy of Art, Hangzhou. The author is grateful for suggestions and information from Dr Yuri Esin of the Khakassian Research Institute, Abakan. The maps are by Peter Hommel.

References:

ANTHONY, D.W. 2007. The horse, the wheel and language: How Bronze-Age riders from the Eurasian Steppes shaped the modern world. Princeton: Princeton University Press. BUNKER, E. 1993. Gold in the ancient Chinese world: A cultural puzzle. Artibus Asiae, 53.1/2: 2750.

BARFIELD, T.J. 1989. The perilous frontier: Nomadic empires and China, 221 BC to AD 1757. Cambridge, MA. \& Oxford: Blackwell.

CAO, D. Z. 2014. The loess highland in a trading network (1300-1050BC), Unpublished PhD dissertation, Princeton University.

CASS, 2003 Zhongguo shehui kexueyuan kaogu yanjiusuo (ed.). Zhongguo kaoguxue: Xia Shang juan. Beijing: Zhongguo shehui kexue chubanshe.

CHERNYKH, E.N. 1992 Ancient metallurgy in the USSR: The Early Metal Age, translated by S. Wright, Cambridge: Cambridge University Press.

CHUGUNOV, K., H. PARZINGER, \& A.NAGLER, 2010. Der skythenzeitliche

Füstenkurgan Aržan 2 in Tuva. Mainz: Verlag Philipp von Zabern.

CURTIS, J. 2000. Ancient Persia. London: British Museum Press.

DI COSMO, N. 2002. Ancient China and its enemies: The rise of nomadic power in East Asian history. Cambridge: Cambridge University Press.

FRACHETTI, M. D. 2012. Multiregional emergence of mobile pastoralism and nonuniform institutional complexity across Eurasia. Current Anthropology, 53.1, 2-38.

FULLER, D.Q. \& M. ROWLAND. 2011. Ingestion and food technologies: Maintaining differences over the long-term in West, South and East Asia, in T.C.Wilkinson, S.Sherratt, and J. Bennett (ed.) Interweaving worlds: Systemic interactions in Eurasia, $7^{\text {th }}$ to the $1^{\text {st }}$ Millennium BC: Essays from a conference in memory of Professor Andrew Sherratt: 37-60. Oxford: Oxbow Books.

GANSU SHENG. 2014. Gansu sheng wenwu kaogu yanjiusuo. Xi Rong yizhen, Majiayuan Zhanguo mudi chutu wenwu. Beijing: Wenwu chubanshe.

HONEYCHURCH W, 2015. Inner Asia and the spatial politics of empire: Archaeology, mobility, and culture contact. New York: Springer.

HSU, Y.K., P.J. BRAY, P. HOMMEL, A.M. POLLARD \& J. RAWSON 2016 Tracing the flows of copper and copper alloys in early Iron Age societies of the Eastern Eurasian steppe. Antiquity 90.350, 357-375.

JACOBSON-Tepfer, E., J.E. MEACHAM, J. E.\& G. TEPFER. 2010. Archaeology and landscape in the Mongolian Altai: An atlas. Redlands, Calif.: ESRI Press.

JACKSON, S. E. \& J. WRIGHT 2014. The work of monuments: reflections on the spatial, temporal and social orientations in Mongolia and the Maya lowlands. Cambridge

Archaeological Journal 24.1: 117-40.

JONES, M., H. HUNT, E. LIGHTFOOT, D. LISTE, D. \& X. LIU. 2011. Food globalisation in prehistory. World Archaeology, 43.4: 665-675.

KARLGREN, B. 1945. Some weapons and tools of the Yin dynasty. Bulletin of the Museum of Far Eastern Antiquities 92: 101-144.

KEIGHTLEY, D. N. 2012. Working for His Majesty. Berkeley: University of California, Institute of East Asian Studies.

KHAYUTINA, M. (ed.) 2013. Qin - The Eternal Emperor and his terracotta warriors. 
Zurich: NZZ Libro.

KUZMINA, E. E. 2008. The prehistory of the Silk Road. V.H. MAIR (ed.). Philadelphia: University of Pennsylvania Press.

LEDDEROSE, L. 2000. Ten thousand things: Module and mass production in Chinese art. Princeton: Princeton University Press.

LI, F. 2006. Landscape and power in early China: The crisis and fall of the Western Zhou, 1045-771 BC. Cambridge: Cambridge University Press.

LI, J. 2015. The Landscape of China's participation in the Bronze Age Eurasian network. Journal of World Prehistory 28.3: 179-213.

LIN, M. C. 2015. New archaeological evidence on the origins of Chinese bronze cultures, Eurasian Studies, 3: 1-12.

LINDUFF, K.M. 1997. An Archaeological overview, in E. BUNKER with T.S. KAWAMI \&, K.M. LINDUFF (ed.). Ancient Chinese bronzes of the Eastern Eurasian Steppes from the Arthur M. Sackler Collection: 18-98. New York: Arthur M. Sackler Foundation.

LINDUFF, K. M. 1998. The emergence and demise of bronze-producing cultures outside the central plain of China, in V. H. Mair (ed.), The Bronze Age and early Iron Age peoples of eastern Central Asia, 2 vols. 619-643. Pennyslvania: The University Museum Publications. LINDUFF, K.M. 2015. What's mine is yours: The transmission of metallurgical technology in Eastern Eurasia and East Asia, in S. Srinivasan and S. Ranganathan (ed.) Materials and civilization:8-14. BUMA VII Proceedings.

LIN, Y. 1986. A re-examination of the relationship between bronzes of the Shang culture and of the Northern Zone, in K. C. Chang ed., Studies of Shang archaeology: Selected papers from the international conference on Shang civilization: 237-273. New Haven \& London: Yale University Press.

LOEHR, M. 1949 Weapons and tools from Anyang and Siberian analogies, American Journal of Arcaheology 53.2: 126-144.

LEGRAND, S. The Emergence of the Scythians: Bronze Age to Iron Age in South Siberia. Antiquity 80.310: 843-859.

MEI, J.J. 2009. Early metallurgy in the Eurasian Steppe and China: Some challenging issues, in J. J. Mei and T. Rehren (ed.) Metallurgy and civilization: Eurasia and beyond: 9-16. London: Archetype Publications.

MEI J. J., K. L. CHEN, A.D. SHAO, J.C. YANG, \& W.G. SUN. 2014. Qinshihuangdi lingyuan chutu qingtong shuiqin de buchuo gongyi ji xiangguan wenti chutan. Kaogu 7: 96104.

MICHAELSON, C. 1999. Gilded dragons: Buried treasures from China's golden ages. London: British Museum Press.

NANJING MUSEUM 2013. Jiangsu Xuyi Xian Dayunshan Xi Han Jingdu Wang ling yihao mu. Wenwu 10:3-68.

RAWSON, J. 2015. Steppe weapons in ancient China and the role of hand-to-hand combat. The National Palace Museum Research Quarterly, 33.1: 37-97.

RAWSON, J. 2016. Revisiting Chinese bronzes, in A. Selbitschaka \& S. Müller (ed.). Essays in Honour of Thomas Höllmann. Wiesbaden: Harrassowitz Verlag (forthcoming).

RUDENKO, S. 1970. Frozen tombs of Siberia: The Pazyryk burials of Iron-Age horsemen. London: Dent.

SHELACH, G. 2009. Prehistoric societies on the northern frontiers of China, archaeological perspectives on identity formation and economic changes during the first millennium BCE. London: Equinox.

SHELACH-LAVI, G. 2015. The archaeology of early China, from prehistory to the Han dynasty. Cambridge: Cambridge University Press. 
SHELACH, G. \& PINES, Y. 2005. Secondary state formation and the development of local identity: change and continuity in the State of Qin (770-221 BC), in M. Stark (ed.), An archaeology of Asia: 202-230. Oxford: Blackwell Publishers.

SHERRAT, A. 2006. The Trans-Eurasian exchange: The prehistory of Chinese relations with the west, in V. MAIR (ed.) Contact and exchange in the ancient world: 30-61. Honolulu: University of Hawaii Press.

SO, J. F. 2014. Foreign/Eurasian elements in Pre-Imperial Qin, in Y. Liu (ed.) Beyond the First Emperor's mausoleum: New perspectives on Qin art: 191-211. Seattle: University of Washington Press.

STARK, S. 2012. Nomads and networks: Elites and their connections to the outside world, in Nomads and networks: The ancient art and culture of Kazakhstan, S. Stark and K. S.

Rubinson et.al.(ed.):106-138. Princeton and Oxford: Institute for the Study of the Ancient World at New York University; Princeton University Press.

TONG, E. Z. 1987. Shilun woguo cong dongbei zhi xinan de biandi banyuexing wenhua chuanbodai. Wenwu yu kaogu lunwenji 17-43. Beijing: Wenwu chubanshe.

UNDERHILL, A. P. 2002. Craft production and social change in northern China. New York: Kluwer Academic/Plenum Publishers.

USDA/ERS and CIESIN, 1996. (United States Department of Agriculture Extension Research Service and Center for International Earth Science Information Network), 1996. China Dimensions Data Collection: Agricultural Statistics of the People's Republic of China: 1949-1990. Palisades, NY: NASA Socioeconomic Data and Applications Center (SEDAC). http://dx.doi.org/10.7927/H4RB72JW. Accessed 09/05/2014.

WAGNER, D. B. 2008. Science and civilization in China, volume 3, Chemistry and chemical technology, part II, Ferrous metallurgy. Cambridge: Cambridge University Press.

WU, E. 2007. Beifang caoyuan kaoguxue wenhua yanjiu: Qingtongshidai zhi zaoqi tieqi shidai. Beijing: Wenwu chubanshe.

WU, H. Y. 2013. Chariots in early China, origins, cultural interaction and identity, Oxford: BAR International Series.

YANG, J. H. \& SHAO, H. Q. 2014. Shang wenhua dui Zhongguo beifang yiji Ouya caoyuan dongbu diqu de yingxiang. Kaogu yu wenwu 3: 45-57.

YATES, R. 1999. Early China, in . K. Raaflaub \& N. Rosenstein (ed.). War and society in the ancient and medieval worlds: 7-45. Cambridge Mass.\& London: Harvard University Press.

Captions

Figure 1. Map of central China and the arc (coloured grey), with sites mentioned in the paper. Map by Peter Hommel.

Figure 2. Map of central China and the Eastern Eurasian Steppe with finds of spearheads with hooks typical of the Seima Turbino Phenomenon, second millennium BC. Map, Peter Hommel.

Figure 3. A group of cast bronze vessels, Shang period, $12^{\text {th }}-11^{\text {th }}$ century BC. British Museum. 
Figure 4. Map of the eastern steppe and the arc showing the distribution of small swords or daggers along the arc. Minusinsk Basin (a-e) [a-Krivosheino (Andronovo), b-Potroshilovo (Okunevo), c-Krasnopol'e, d-Kaptyrevo, e-Chasto-ostrovsoke]; Mongolia (f-h): g-Galt, Khovshol Province, h-Battsengel, Arkhangay Province, i-Chance Find, Ömnögovi Province; China (i-u): i-Tianshanbeilu, Xinjiang, j-Xuhaishuwan, k-Chaodaogou, l-Baifu, mNanshangen, n-Shaoguoyingzi, o-Ningcheng City, p-Liulihe, q-Xi'an, r-Baicaopo, s-Baoji Zhuyuanguo, t-Chengdu. Map and drawings by Peter Hommel.

Figure 5. Symbolic jade weapon, ge. Shang dynasty, $12^{\text {th }}$ century BC. Shanghai Museum. Author's photograph.

Figure 6. Map of the steppe and Central Asia with major Iron Age sites. Map and drawings by Peter Hommel.

Figure 7. Drawing of a suggested arrangement of gold from tomb M27 at Liangdaicun, Hancheng, Shaanxi Province, $8^{\text {th }}$ century BC. Drawing by John Rawson based on a sketch of the reconstruction shown at the Shanghai Museum, September 2012. 
Pictures for Rawson paper 


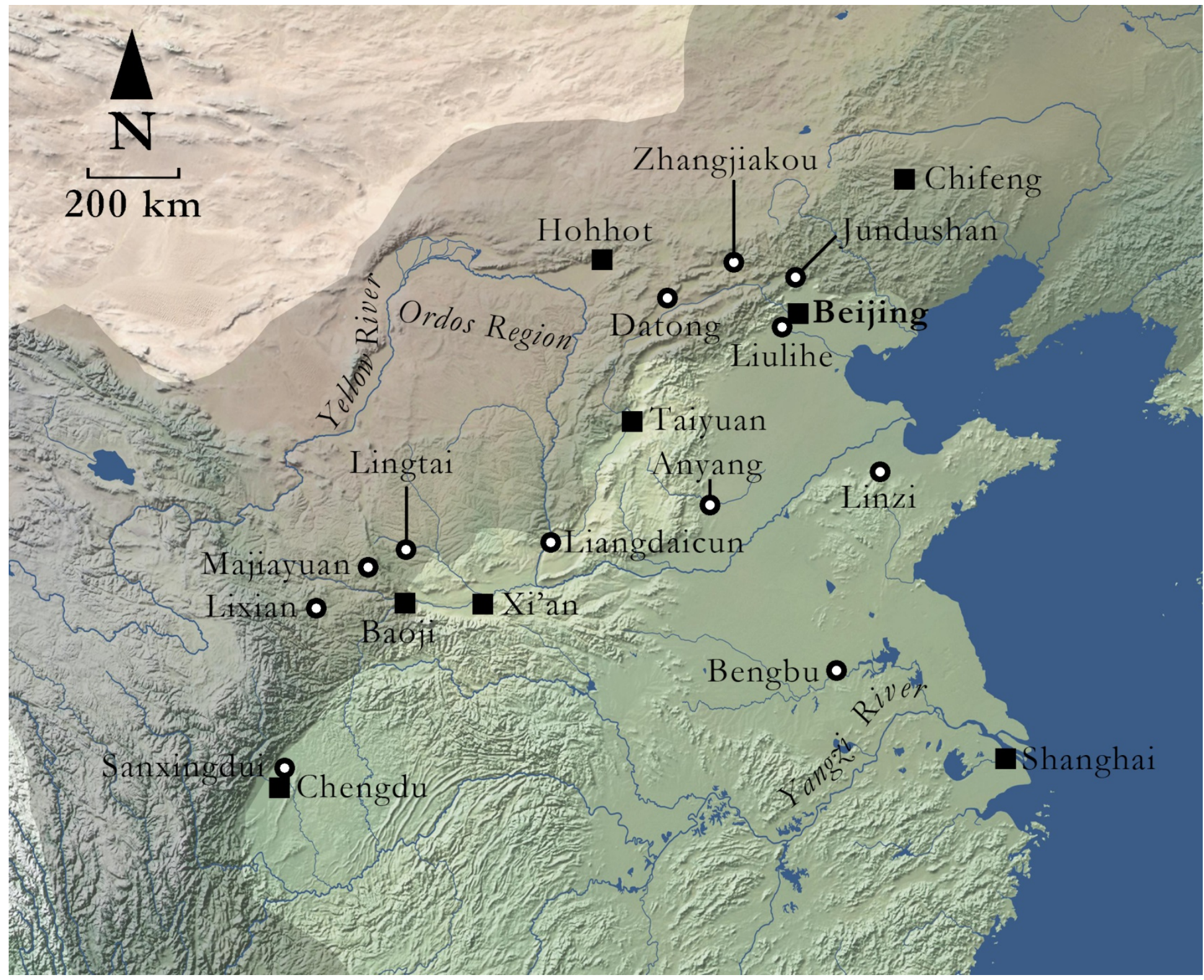

Rawson Fig 1 


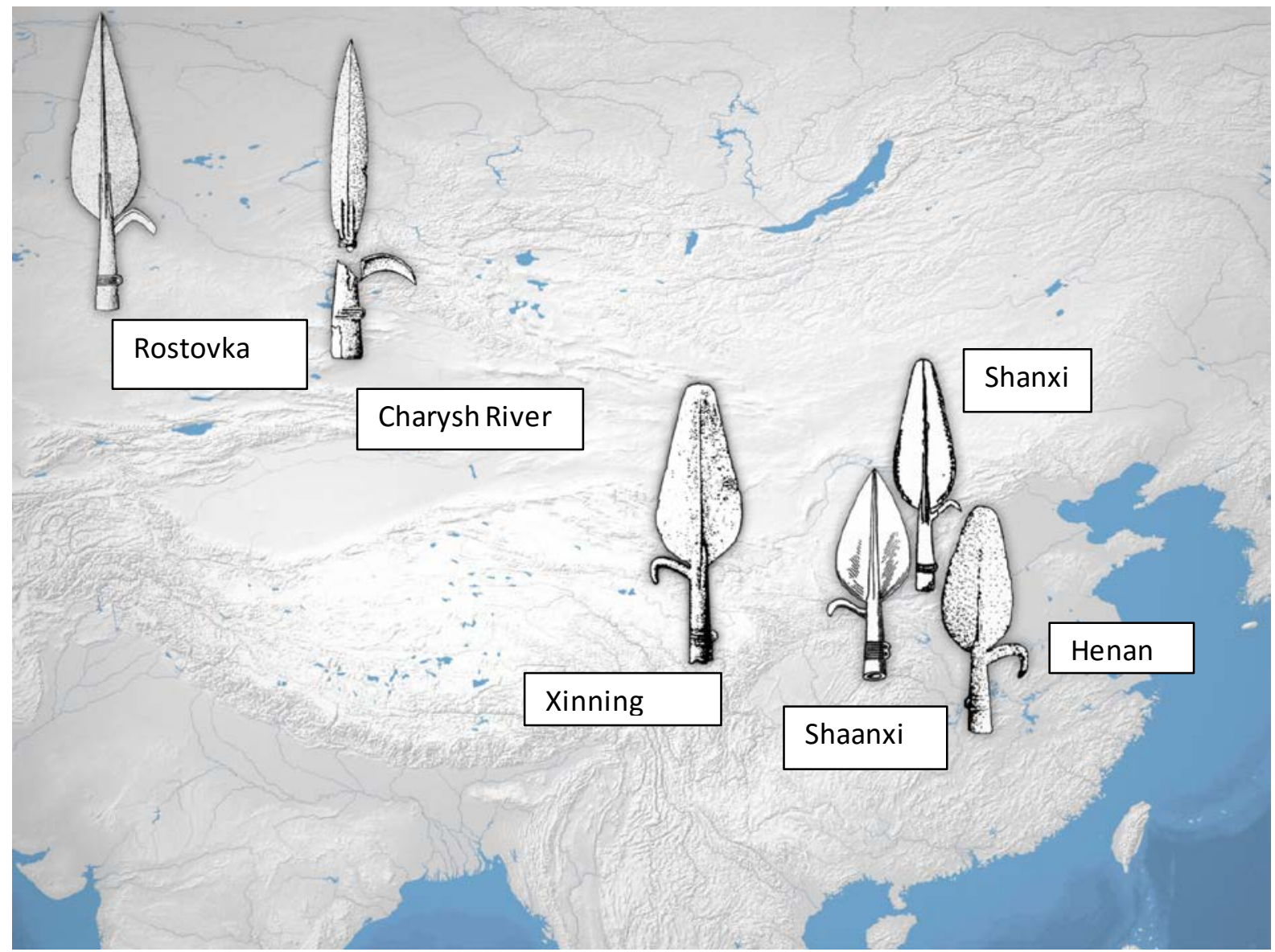

Rawson Fig 2 


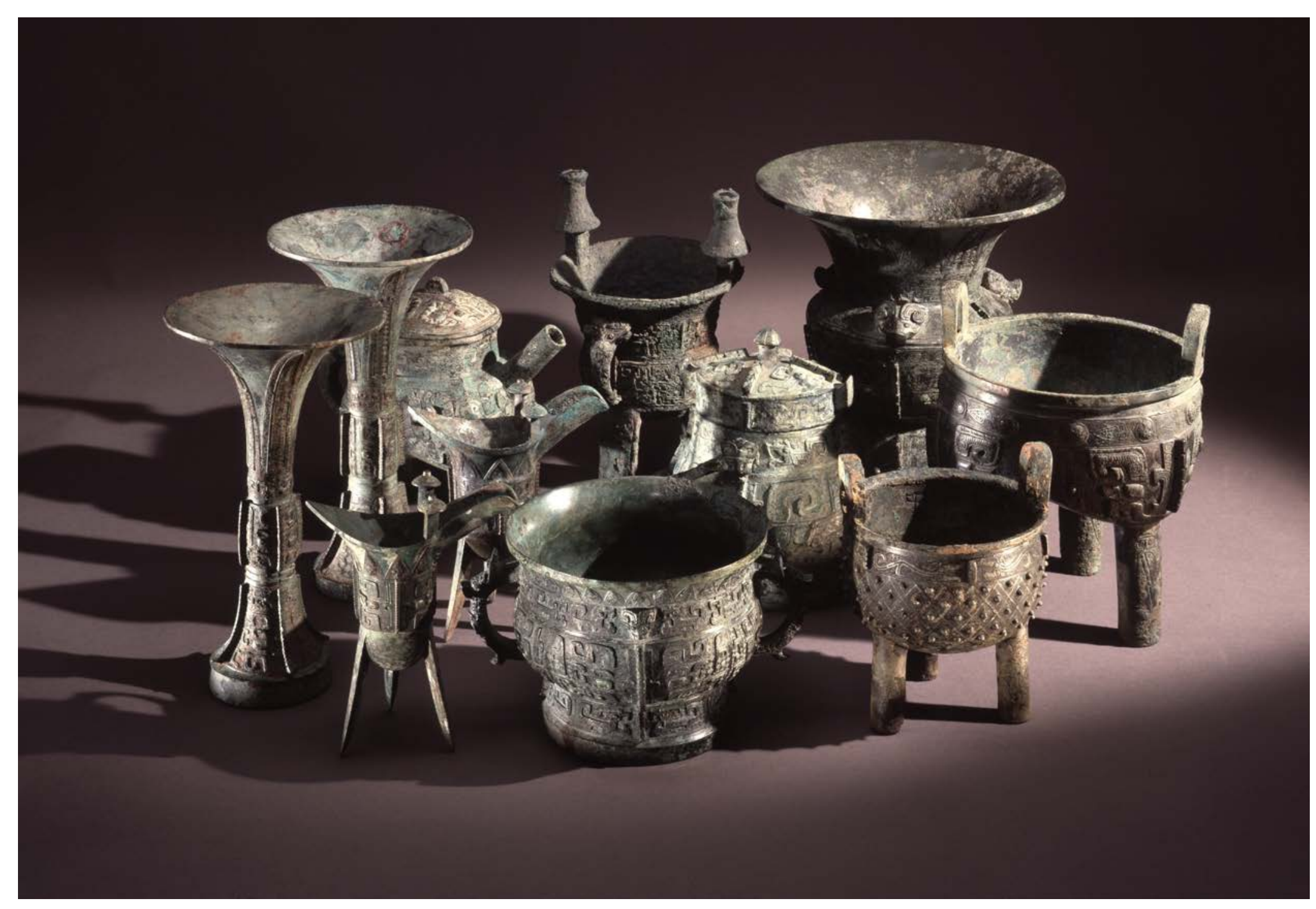

Rawson Fig. 3 


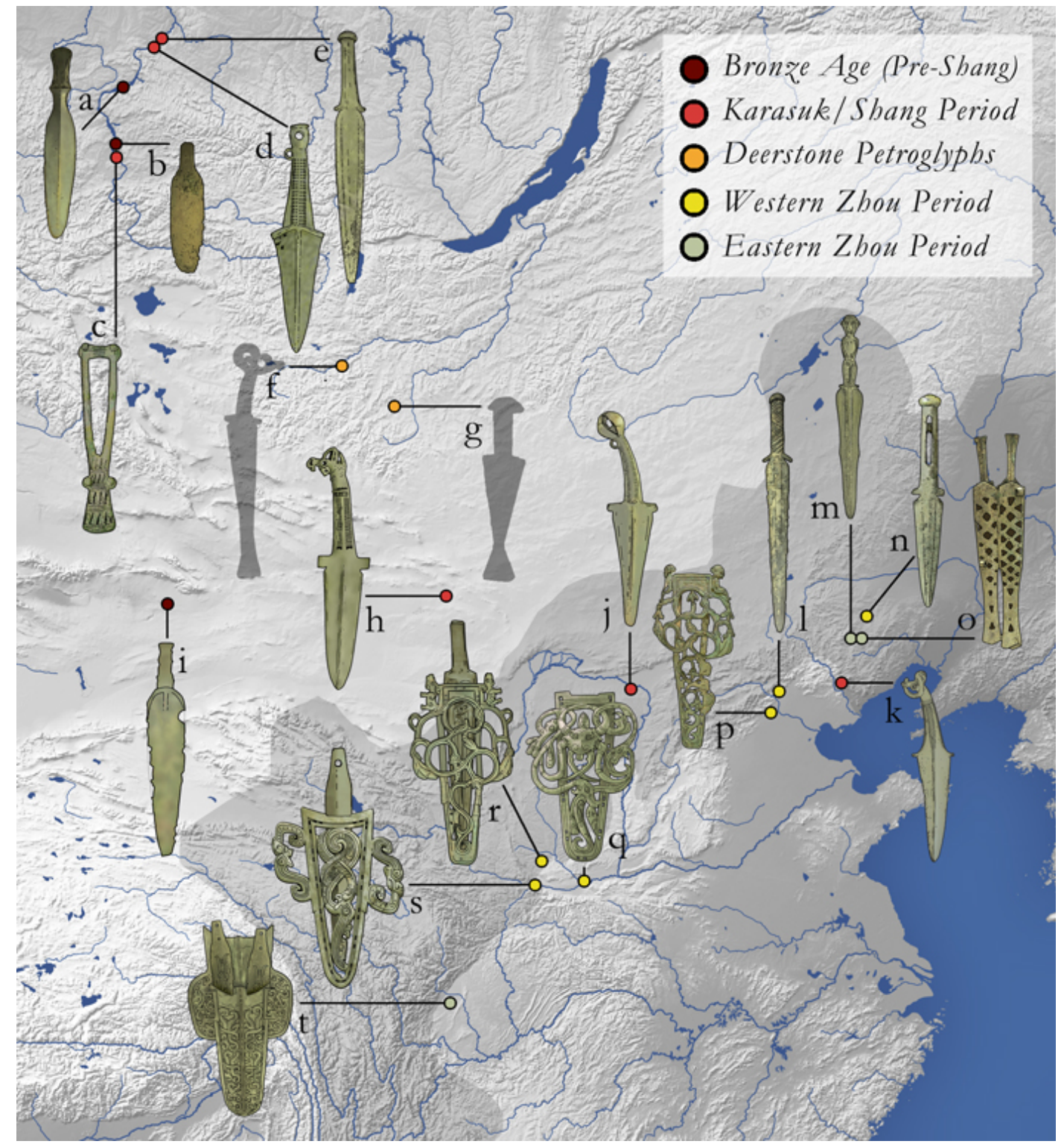

Rawson Fig. 4 


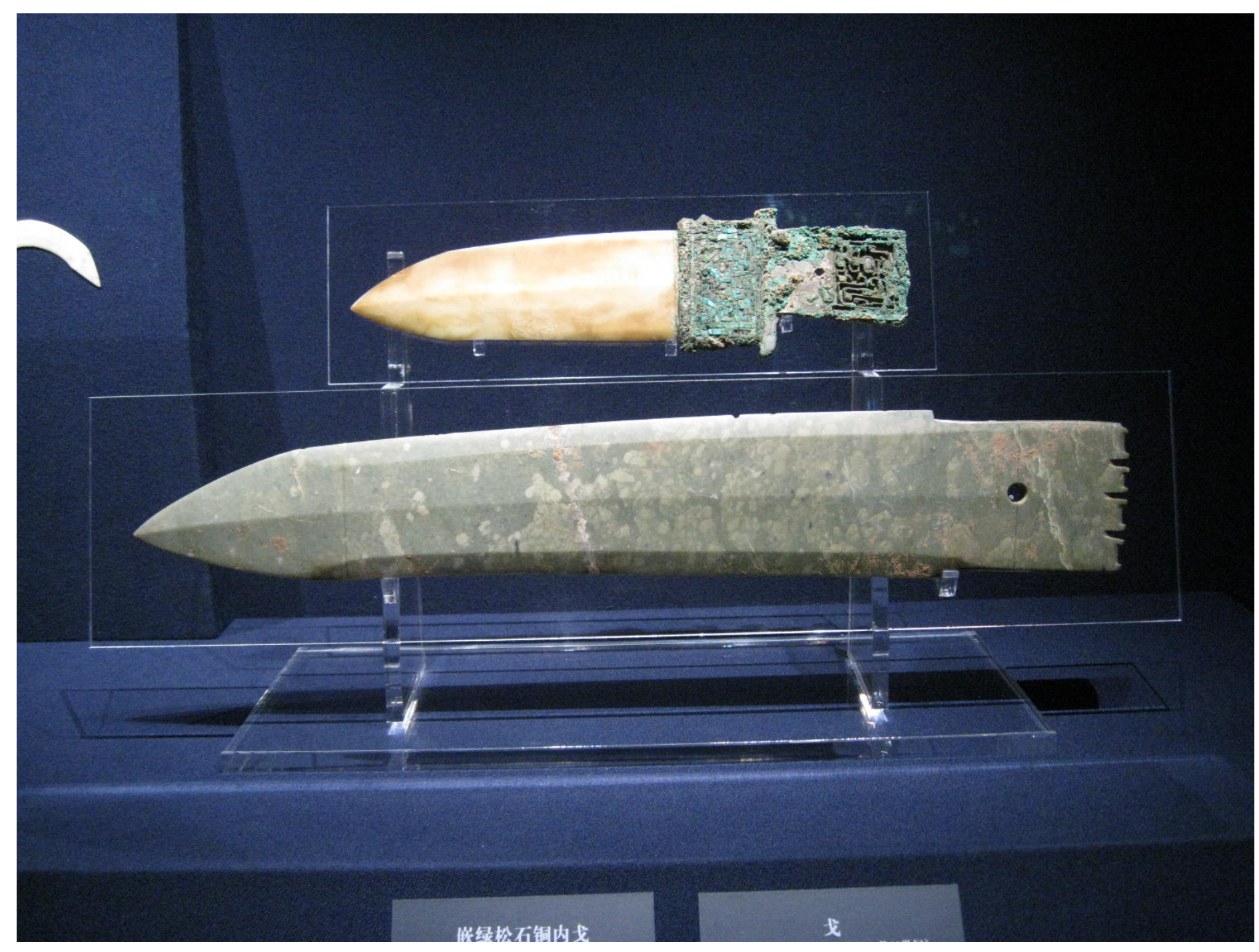

Rawson Fig 5

Only use the lower image 


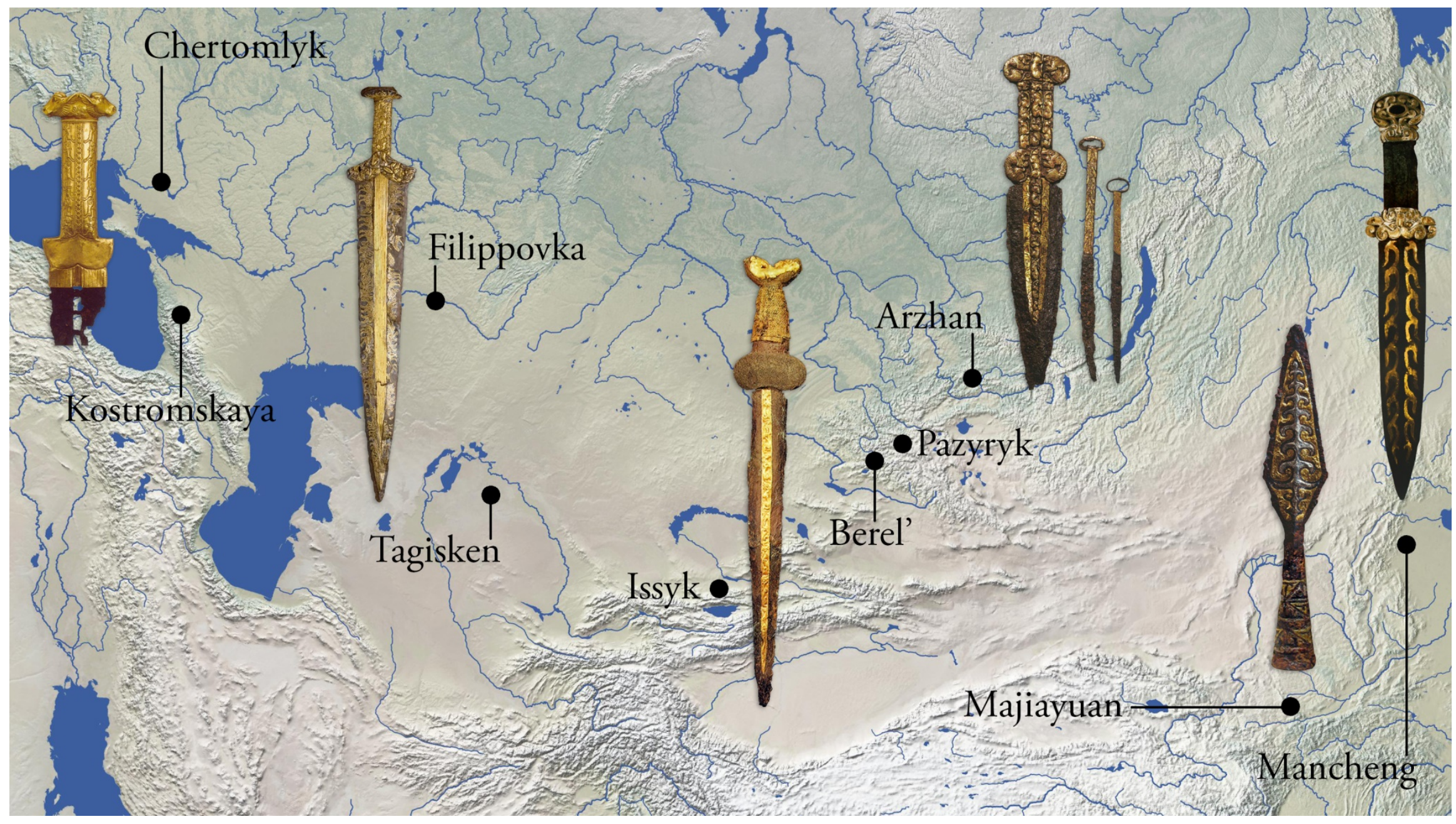

Rawson Fig. 6 
